\title{
URBAN RESILIENCE:
}

\section{WHAT ROLE CAN BUSINESS IMPROVEMENT AREAS PLAY IN INCREASING CLIMATE CHANGE AND EXTREME WEATHER RESILIENCE IN CITIES?}

\author{
by \\ Brodie Robert Michael Johnson \\ BA Urban Studies, University of Calgary, 2015 \\ A Major Research Paper \\ presented to Ryerson University \\ in partial fulfillment of the requirements for the degree of \\ Master of Planning \\ in \\ Urban Development
}

Toronto, Ontario, Canada, 2017

(c) Brodie Johnson, 2017 


\section{AUTHOR'S DECLARATION}

I hereby declare that I am the sole author of this MRP. This is a true copy of the MRP, including all required final revisions.

I authorize Ryerson University to lend this MRP to other institutions or individuals for the purpose of scholarly research.

I further authorize Ryerson University to reproduce this MRP by photocopying or by other means, in total or in part, at the request of other institutions or individuals for the purpose of scholarly research.

I understand that my MRP may be made electronically available to the public. 


\title{
URBAN RESILIENCE:
}

\section{WHAT ROLE CAN BUSINESS IMPROVEMENT AREAS PLAY IN INCREASING CLIMATE CHANGE AND EXTREME WEATHER RESILIENCE IN CITIES?}

Brodie Johnson, 2017

\author{
Master of Planning \\ in \\ Urban Development \\ Ryerson University
}

\begin{abstract}
Climate change and extreme weather has caused significant damage to critical infrastructure of cities. This paper examines the unique role that Business Improvement Areas (BIAs) can play in increasing climate change and extreme weather resilience.

This study was informed by a review of existing resilience initiatives undertaken in Toronto and Vancouver and a series of semi-structured interviews with City and BIA staff to understand the current opportunities and barriers to BIA involvement. A series of ten recommendations informed by research and interview analysis discusses how BIAs can become better equipped to partner with cities to increase climate change and extreme weather resilience.
\end{abstract}

Key Words: Business Improvement Areas; resilience; climate change; extreme weather 


\section{ACKNOWLEDGEMENTS}

I would like to thank my supervisor, Dr. Mitchell Kosny and my second reader, Evan

Weinberg, for their trust, guidance, humour, insight, and incredible support and encouragement throughout this research. Additionally, I would like to thank the interview participants for their sharing their time and expertise with me. The work BIA and City staff do to advance local and municipal initiatives is invaluable.

Finally, I would like to sincerely thank my family for their love and support and in particular my wife Alyssa, for her superhuman patience throughout this incredible journey. 


\section{TABLe of Contents}

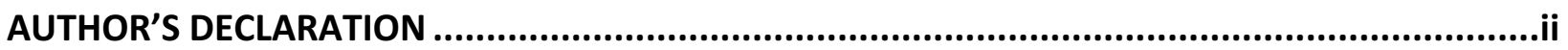

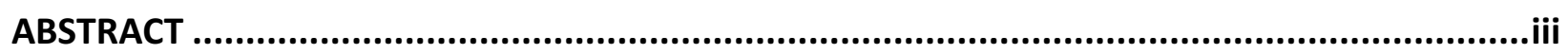

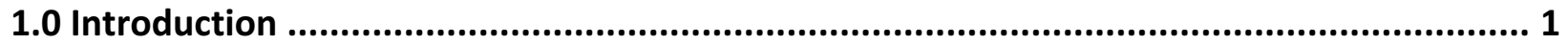

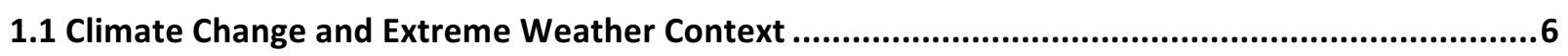

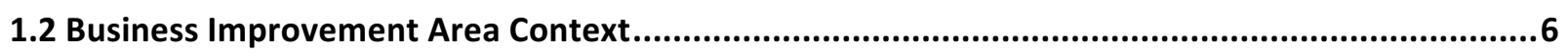

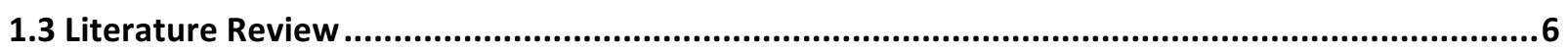

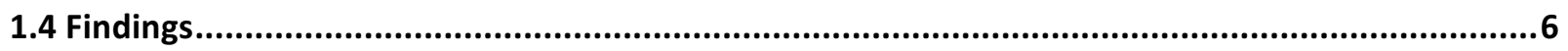

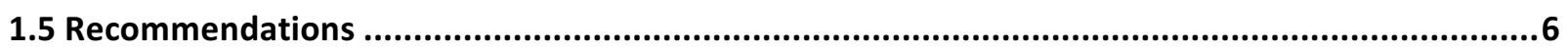

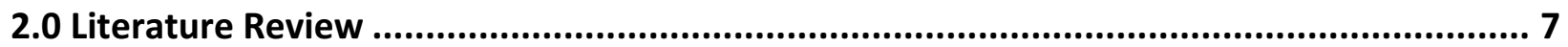

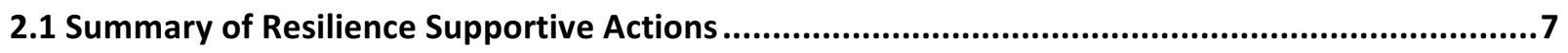

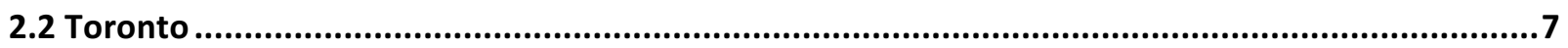

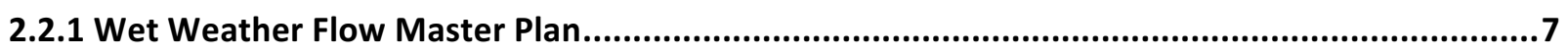

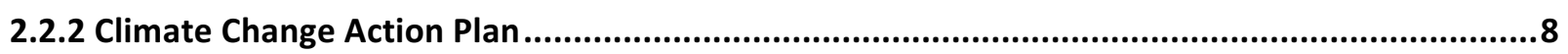

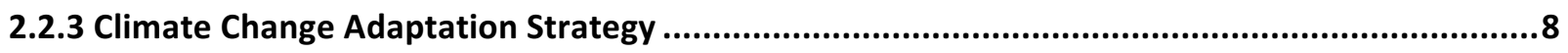

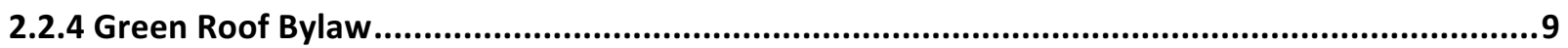

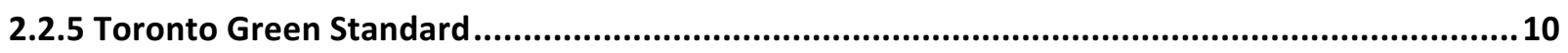

2.2.6 Resilient City Working Group.............................................................................................10

2.2.7 Climate Change Risk Management Policy ..........................................................................11

2.2.8 Parks and Environment Subcommittee on Climate Change Mitigation and Adaptation............11

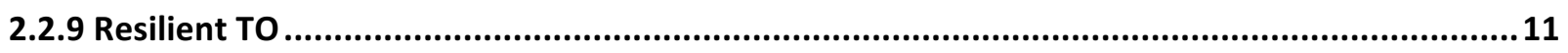

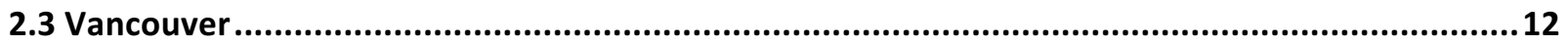

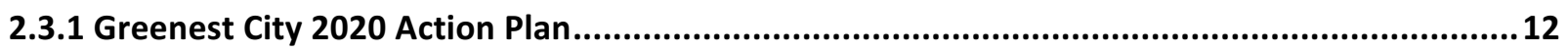

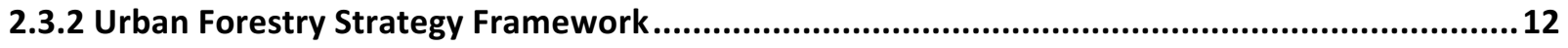

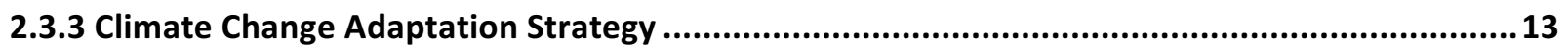

2.3.4 Citywide Integrated Rainwater Management Plan..............................................................13

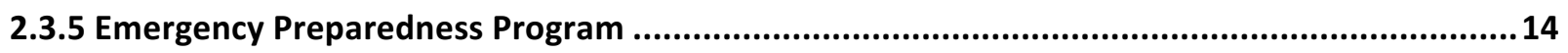

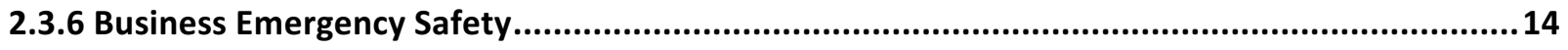

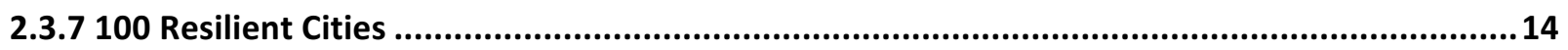

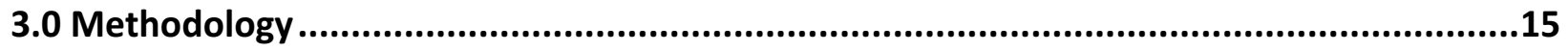

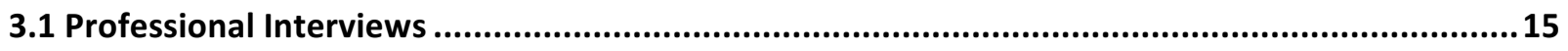

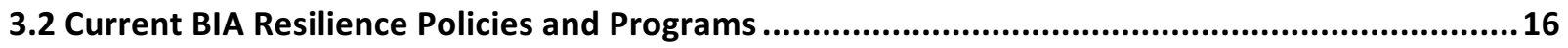

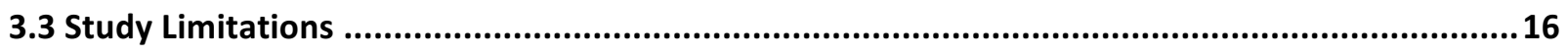

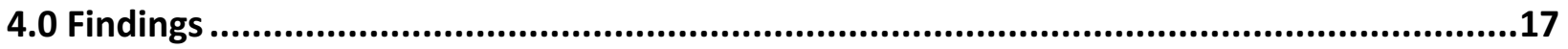

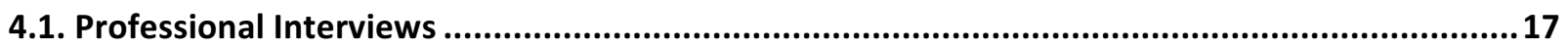

4.2 Toronto BIA Resilience Policies and Programs Findings............................................................22

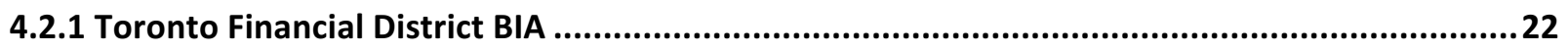

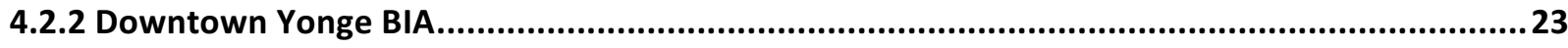

4.3. Vancouver BIA Resilience Policies and Programs Findings.....................................................23 
4.3.1 Downtown Vancouver BIA....................................................................................23

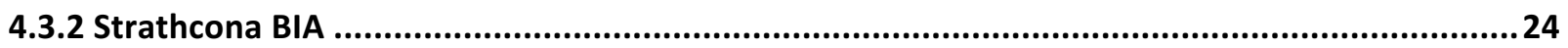

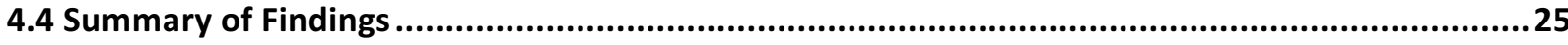

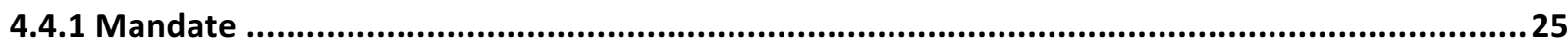

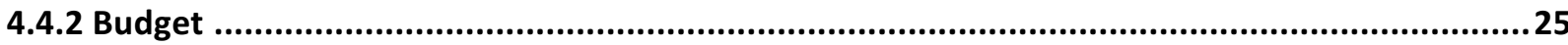

4.4.3 Capacity ..................................................................................................26

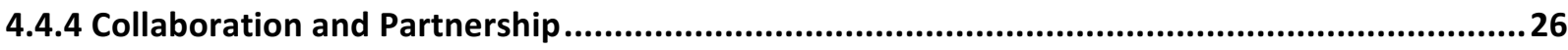

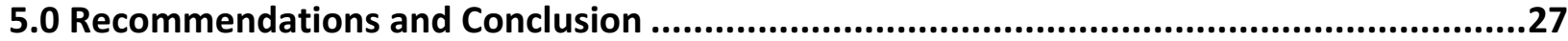

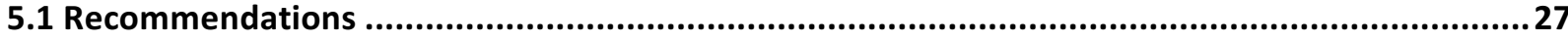

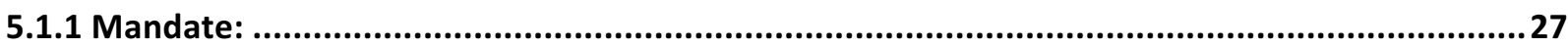

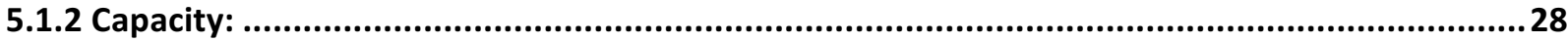

5.1.3 Collaboration and Partnership:.........................................................................28

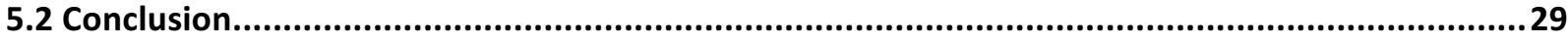

Appendix: Professional Interview Questions ...............................................................30

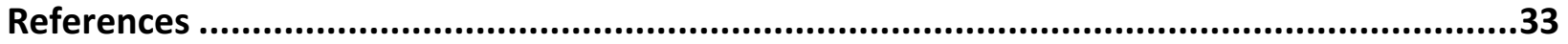

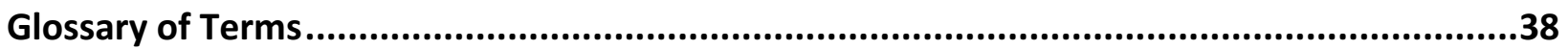




\subsection{INTRODUCTION}

One of the key challenges facing cities today is climate change and the increasing risk of extreme weather events damaging critical infrastructure. Cities around the world have experienced significant economic losses due to extreme weather events in the past several years, and the numbers continue to increase over time.

In 2016, global economic losses due to natural disasters and extreme weather events totaled $\$ 175$ billion (Munich, 2017), a marked increase from the total global losses experienced in 2014 of $\$ 110$ billion (Munich, 2015). Extreme weather events are expected to increase in the coming years. In Toronto alone, the city is expected to experience less extreme rain days, but a greater volume of rain output during those days, higher maximum and average temperatures, and an increasing number of heat waves (City of Toronto, 2013). Another unfortunate side effect of climate change is the increasing number record weather events occurring in cities.

In Toronto, only a single year between 2000 and 2012 saw no observed record weather events, with numerous records being broken including several rainfall and precipitation records, such as the wettest observed summer in 53 years, record volume in a single rainfall, highest July maximum temperature, and number of days recorded above $30 \mathrm{C}$ (City of Toronto, 2013). Since 2000, Toronto has seen several 1-in-100 year storms, notably the extreme weather event of 2005 , in which a one-hour rainstorm was estimated to have cost the City of Toronto $\$ 47$ million in infrastructure repairs, including road washouts (City of Toronto, 2012) and the rainstorm event of July 8, 2013, in which it was estimated that the City of Toronto and the Toronto and Region Conservation Authority 
(TRCA) suffered over $\$ 70$ million in revenue losses and expenditures as a result of damaged infrastructure (City of Toronto, 2013). Additionally, it was reported by the Insurance Bureau of Canada that these two extreme weather events alone combined for nearly $\$ 1.5$ billion in private insurance claims (City of Toronto, 2013).

In Calgary, the 2013 extreme weather rainstorm event produced the worst flooding in the province's history, the most expensive rainstorm event in Canadian history, and one of the largest natural disasters in Canadian history. It is estimated that losses incurred by result of the flooding total nearly $\$ 6$ billion of private damage and public infrastructure damage, which includes more than 985 kilometers of damaged provincial roads (MNP, 2015).

New York's 2012 Hurricane Sandy provides a grim reminder of the human effects of extreme weather, in which 43 people lost their lives (New York, 2013). The storm wreaked havoc across the City and State and has been reported to have caused $\$ 19$ billion in economic losses, and costing the City of New York billions more in infrastructure damage (City of Toronto, 2014), while leaving nearly 2 million people without power in the aftermath (New York, 2013).

Vancouver windstorms in 2006 left over 250,000 people without power and cost the City an estimated $\$ 10$ million in infrastructure damage, forest and slope restoration expenditures, and planning costs. Additionally, extreme rainfall in 2010 resulted in over 170 claims filed against the City (City of Vancouver, 2012). Finally, according to the National Round Table on the Environment and the Economy (NRTEE) (2012), predicted 
sea level rise may cause in excess of $\$ 7.6$ billion in damages primarily to the Metro Vancouver area.

Extreme weather events like these have proven powerful impetus to spearhead investment in resilience at all levels of government. For this study, resilience is defined using the Rockefeller Foundation's definition of "the ability of a system, entity, community, or person to withstand shocks while still maintaining its essential functions and to recover quickly and effectively" (100RC, 2013).

Investment in resilience carries long-term economic benefits, including mitigating future losses in infrastructure damage and productivity after extreme weather events. Benefits of avoided and reduced losses can outweigh upfront investment costs by an average of four to one (World Bank, 2013), and can return even higher benefits as the NRTEE (2012) estimates that $\$ 25$ billion worth of real estate damage in Vancouver can be mitigated through infrastructure investments estimated at costing between $\$ 255$ million and $\$ 510$ million. This data suggests that there is a significant cost of inaction on climate change adaptation; specifically, public safety and infrastructure maintenance and repairs could prove to be significantly higher in the aftermath of extreme weather events, rather than proactively planning and building resilience initiatives into current and future plans (City of Toronto, 2014). Vorhies and Wilkinson (2016) also present an interesting notion of a co-benefit principle, whereby building resilience to climate change and extreme weather events can provide several secondary or spin-off benefits, such as economic and social benefits. 
Significant challenges do exist, however, as infrastructure investments often sought can have high upfront capital costs and it is important for cities to seek innovative and collaborative approaches to funding initiatives. Cities already utilize partnership models for infrastructure projects to reduce construction costs and mitigate risk (Infrastructure Ontario, 2015) and City climate change strategic plans call for increased partnership and collaboration across all sectors (City of Toronto, 2017). A unique opportunity exists for partnership and collaboration with Business Improvement Areas (BIAs), who possess intimate local knowledge of their areas, carry mandates of economic development and are privately funded through a special levy on commercial businesses within a defined geography.

BIAs are an innovation that allows business property owners and tenants to facilitate physical improvements and promote economic development within the areas they work (MMAH, 2010). Through legislation, BIAs function under the premise that members within the established boundary of the area pay an added tax or levy along with their annual property taxes. This levy provides a stable source of funding towards a myriad of different goals and objectives set forth by the BIA, which can include physical streetscape improvements, street beautification, marketing and promotion, and economic development (MMAH, 2010; City of Edmonton, 2010, City of Calgary, 2016).

Business Improvement Areas were invented in Ontario, with the first created being Toronto's Bloor West Village in 1970. Since then, the number of BIAs in Toronto has expanded to over 80 and the BIA concept has spread across the world in one form or another with increasingly significant roles played within communities (Blackman, 2008). In North America alone, as of 2012 there were more than 1,700 BIAs (Gomez, Isakov, \& 
Semansky, 2015) and according to the International Downtown Association (2017), the top five Canadian cities receive direct private investment from BIAs totaling over $\$ 70$ million per year.

BIAs come in a variety of shapes and sizes; some concentrated along retail high streets, and some covering broad geographic areas; some with relatively small budgets, and some with budgets stretching into the millions. The average budget of Toronto's five largest downtown BIAs in 2016 was $\$ 2.050$ million (City of Toronto, 2015) and have made great strides in promoting vibrant economic conditions in their areas, while becoming true players at the planning table by possessing an intimate local knowledge of their respective areas.

This study will explore what methods select North American cities are using to tackle the issue of resilience and how Business Improvement Areas can insert themselves into the conversation of increasing resilience within their boundaries, and what impact that may have in affecting the broader resilience initiatives of their respective cities. This research will answer the question:

What role can Business Improvement Areas (BIAs) play in increasing climate change resilience in cities?

This paper is structured systematically to progress towards providing a series of recommendations to enable or improve the position of BIAs to make meaningful, incremental resilience improvements within their areas. The paper's components are listed and discussed below: 


\subsection{Climate Change and Extreme Weather Context}

An introductory exploration of climate change and extreme weather will highlight their impacts on city critical infrastructure and the significant damages incurred and provide a powerful impetus for forward resilience initiatives.

\subsection{Business Improvement ARea Context}

An exploration of BIAs will be conducted that will help to explain their rising prominence as champions of local areas. Examining current BIA mandates and structures is critical to understanding the unique position of BIAs in resilience contexts.

\subsection{LiteRATURE REVIEW}

A scan of existing programs and actions supporting resilience in Toronto and Vancouver will demonstrate the value and challenges of resilience initiatives in local, regional and global contexts. This scan will also serve to underscore the need for innovative approaches to funding resilience initiatives.

\subsection{FINDINGS}

Building on the work completed, specific questions were developed and the primary interview responses will be analyzed to understand current barriers and opportunities to BIA involvement with resilience initiatives. A survey of existing initiatives that select BIAs are undertaking to directly or indirectly support resilience building will demonstrate current capacity.

\subsection{ReCOMmENDATIONS}

Using the work completed in this research, major themes are identified that inform the recommendations made to enhance BIA positions as viable and capable stakeholders for cities to partner with to improve their resilience. 


\subsection{LITERATURE REVIEW}

\subsection{Summary OF Resilience Supportive Actions}

Toronto and Vancouver were selected for conducting a scan of resilience support actions summary based on their ongoing leadership and vanguard position with climate change resilience. In their resilient cities report, Grosvenor, a privately-owned property group ranks Toronto and Vancouver \#1 and \#2 respectively on the basis of vulnerability and adaptive capacity scores (Grosvenor, 2014). Vulnerability scores were calculated using factors such as climate change threats and level of transportation and utility infrastructure. Adaptive capacity scores were calculated using factors such as governance structures, planning systems and funding structures.

\subsection{TORONTO}

The City of Toronto has engaged in numerous initiatives to increase climate change resilience within their city across its many different departments, agencies, and corporations. Presented here is a high-level summary of select programs, actions, and governance capacities that emphasize the work that Toronto is doing in support of resilience.

\subsubsection{Wet Weather Flow Master Plan}

Toronto's Wet Weather Flow Master Plan (WWFMP) was adopted in 2003 and is among the first resilience and stormwater management related initiatives put forth and implemented by the City of Toronto. The WWFMP is a 25 -year plan and includes provisions to improve the health of Toronto's numerous watercourses and waterfront by reducing the negative effects of stormwater runoff, including the protection of City infrastructure (City of Toronto, 2017). 
A five-year summary report released in 2009 highlights achievements of the plan such as the green roof incentive program to address stormwater runoff at the source, resulting in issuing $\$ 200,000$ in incentives based on amount of green roof installed per square meter (City of Toronto, 2009).

\subsubsection{Climate Change Action Plan}

Adopted in 2007, the Plan focuses on targets to reduce greenhouse gas emissions and create a sustainable future for the City of Toronto. Resilient relevant specifics include (City of Toronto, 2007):

- A commitment for Toronto to double its tree canopy from $17 \%$ in 2011 to between $30 \%$ and $50 \%$ to reduce stormwater runoff and the urban heat island effect; and

- Set forth in motion the development of strategies to address the city's adaptation to climate change.

\subsubsection{Climate Change Adaptation Strategy}

Adopted in 2008, the Climate Change Adaptation Strategy was borne out of the City's Climate Change Action Plan, and sets forth directives to outline actions to improve Toronto's resilience to climate change and extreme weather events, while spawning several reports:

- Resilient City: Preparing for Extreme Weather Events (City of Toronto, 2013) was moved in 2013 to highlight the assessment of City infrastructure capacity and resilience to future extreme weather events and outline future activities to increase resilience of City assets and services to extreme weather conditions; and 
- Resilient City: Preparing for a Changing Climate (City of Toronto, 2014) was moved in 2014 to outline the continued need to increase the city's resilience to extreme weather, underscored by pointing to contemporary extreme weather events in 2013.

The report also included recommendations to require all City agencies to adopt climate change policies and explore partnerships with not only broader public sector entities, but private sector opportunities as well.

\subsubsection{GREEN ROOF BYLAW}

Toronto's Green Roof Bylaw was adopted in 2009 and was the first of its kind in North America, requiring all new construction developments to incorporate green roofs ${ }^{1}$ into its architecture. Specific elements of the bylaw include (City of Toronto, 2017):

- Enforcement through City of Toronto municipal bylaw and applies to all new building permit applications for commercial and institutional developments (residential building that are less than $20 \mathrm{~m}$ or 6 storeys in height are exempt) submitted after January 31, 2010, with later enhancements in 2012 required all new industrial developments to comply with the bylaw as well; and

1. According to the City of Toronto Act, a green roof is defined as a "roof surface that supports the growth of vegetation over a substantial portion of its area for water conservation or energy conservation". 
- The bylaw sets targets for percentage coverage of roof space based on the Gross Floor Area (GFA) of the building development, ranging from $20 \%$ to $60 \%$ based on the size.

\subsubsection{TORONTO GREEN STANDARD}

The Toronto Green Standard (TGS), adopted in 2013, is a set of tiered performance measure requirements and incentives for sustainable building development. The tiers are broken down as follows (City of Toronto, 2017):

- Tier 1 is required for all new developments and includes enforced requirements, such as $15 \%$ energy efficiency improvements over the Ontario Building Code $(\mathrm{OBC})$, stormwater retention features to reduce stormwater runoff, and mandatory tree planting with minimum soil volumes; and

- Tier 2 sets more demanding targets than Tier 1 but is voluntary, providing financial incentives such as rebates on Development Charges (DCs) paid to the City.

\subsubsection{ResiLient City Working Group}

Established in 2013, the Resilient City Working Group (RCWG) is a collaborative and cross corporate effort between the City of Toronto and its relevant agencies, divisions, and corporations and external stakeholders to address climate change resilience. The

group acts in an advisory capacity, providing expert knowledge and technical support for City operations and reports to the Executive Environment Team, which serves as the Steering Committee for the City's Resilient City initiative (City of Toronto, 2017). 


\subsubsection{Climate Change Risk Management Policy}

Adopted by City Council in 2014, the Climate Change Risk Management Policy sets a directive to identify and act to mitigate risks of climate change. Included in the policy are commitments such as (City of Toronto, 2017):

- Inform priorities for investment to mitigate risk to City assets;

- Evaluate initiatives the City undertakes through a resilient lens; and

- Building awareness and to establish partnerships with the public and private sector.

\subsubsection{Parks and Environment Subcommittee on Climate Change Mitigation and ADAPTATION}

A City of Toronto Committee established in 2015 to "report on a review of City policies, expert advice and internal best practices to mitigate and adapt to climate change..." (City of Toronto, 2017).

\subsubsection{RESILIENT TO}

In 2016, Toronto obtained membership into the 100 Resilient Cities Network (100RC). This means the City of Toronto will receive a host of benefits including tools and funding to continue development of resilience strategies and financial support to assist with hiring a Chief Resilience Officer (CRO). According to the 100RC (2015), the CRO's responsibilities are to coordinate resilience efforts across government departments, identify a broad umbrella of stakeholders to address challenges, spearhead development of a Resilience Strategy, and apply resilience initiatives in broad strokes across the City's portfolio of services. At the time of writing this paper, the City of Toronto was still searching for a CRO. 


\subsection{VANCOUVER}

\subsubsection{Greenest City 2020 Action Plan}

Passing council approval in 2011, Vancouver's Greenest City 2020 Action Plan (GCAP) sets the goal of being the greenest city in the world by 2020. GCAP is a comprehensive plan to make Vancouver more green, sustainable and resilient through numerous measurable goals and initiatives such as (City of Vancouver, 2015):

- Tree planting target numbers;

- Increasing the tree canopy cover from $18 \%$ to $22 \%$;

- Reducing stress on critical energy infrastructure systems by reducing energy use and emissions by $20 \%$ in existing buildings; and

- Doubling the number of economic opportunities in the green economy by 2020 .

\subsubsection{URBAN FoRESTRY StRATEgY FrameWORK}

Work started on the strategy in 2011 following its identification as a priority item under the Greenest City 2020 Action Plan as Vancouver's tree canopy had declined from $22.5 \%$ to $18 \%$ in twenty years. The strategy sets forth actions for developing and increasing its urban forest such as (City of Vancouver, 2017):

- Planting 150,000 trees by 2020 ;

- Guidelines managing the urban forest lifecycle; and

- Updating plans, policies, and practices addressing climate change. 


\subsubsection{Climate Change Adaptation Strategy}

In 2012, the City of Vancouver developed a strategy to increase the resilience of its critical infrastructure, along with essential services and programs to climate change, which included a strong mandate to enhance opportunities for coordination and cooperation through partnerships and specific actions including (City of Vancouver, 2012):

- Developing stormwater management techniques alongside increasing capacity of the storm sewer system to reduce stress on sewer infrastructure;

- Consideration of projected rainfall numbers when developing new sewer and street design guidelines;

- Increase resilience capacity for responding to and recovering effectively from forecasted increased frequency and severity of extreme weather events;

- Build climate adaptation measures into Vancouver Building Bylaw (VBBL), including exploration of potential zoning changes; and

- Reducing the urban heat island effect through increasing long-term health of urban forests and trees.

\subsubsection{Citywide Integrated Rainwater Management Plan}

Vancouver's 2016 Citywide Integrated Rainwater Management Plan (IRMP) is a green infrastructure strategy designed to meet goals of the Greenest City Action Plan. Direction to includes implementing best practices in water management, through a combination initiatives such as (City of Vancouver, 2016):

- Including preparing for climate change and extreme weather; and 
- Identifying incremental actions including stormwater source controls that reduce runoff, improve water quality and filter stormwater such as permeable paving, absorbent landscapes, green roofs, and bioswales.

\subsubsection{Emergency Preparedness Program}

The City of Vancouver has implemented initiatives to mitigate the effects of emergencies and disasters through committing resources to improving public buildings, infrastructure, roads and bridges. The City has invested to upgrade portions of its aging inventory of bridges to make them more seismically resilient, adopted new design guidelines and techniques for effective stormwater management, with a goal upgrading all combined sewers to separated sewers by 2050 to reduce the risk of flooding during extreme rainfall events.

Additionally, the City has prepared an Earthquake Preparedness Strategy, identifying 56 actions to effectively manage an earthquake event and reduce its impacts on infrastructure, along with numerous emergency communication systems for awareness and information dissemination (City of Vancouver, 2017).

\subsubsection{Business EMERgEnCY SAFETY}

The City of Vancouver outlines best practices for businesses and residents to develop a Business Continuity Plan in the event of business interruptions or disasters that could be caused by extreme weather, to restore business operations quickly effectively (City of Vancouver, 2017).

\subsubsection{ResiLient Cities}

Vancouver was selected in 2016 to join the $100 \mathrm{RC}$ network and is currently in the process of hiring a CRO. 


\subsection{Methodology}

This research is divided into three individual parts: professional interviews, current BIA resilience policies and programs, and limitations of the research. This research received Ryerson University Ethics Review Board approval on February 22, 2017 to include interviews with human participants.

\subsection{Professional INTERVIEWS}

Qualitative interviews were used for this research study. Face to face and over the phone interviews were conducted over a period of three weeks. An approved, pre-determined set of questions were used during semi-structured interviews. The interview questions were made available prior to the interview if the interviewee wished so. The interview questionnaire was submitted to and approved by the Ryerson University Ethics Board prior to the interviews and is provided in Appendix A. Questions were framed and asked in a way to draw out both current practice and opinion regarding processes, challenges, and opportunities regarding resilience initiatives. Interviewees were selected based on experience, expertise, and holding relevant positions regarding involvement in resilience initiatives with either BIAs or within City departments and agencies.

Cities were identified based on their inclusion into the 100 Resilient Cities (100RC) initiative. This is important to note as cities part of the 100RC initiative are provided with financial resources to hire Chief Resilience Officers (100RC, 2017), and demonstrates their commitment to advancing their own resilience agendas. 


\subsection{Current Bia Resilience Policies and Programs}

Selected policies and programs of BIAs were examined to understand current resilience capacity. Though not exhaustive, the analysis seeks to understand what initiatives BIAs have undertaken and will help inform future recommendations.

\subsection{Study Limitations}

Limitations exist with each of the research methods used and are discussed with which to understand the forward findings presented. The interview process is not without limitations as is not indicative of a random sample as the selection of interviewees was made through general knowledge of the researcher, contacts in the field, and what information could be gleaned through internet and website searches. Time constraints also existed with the interview process and secondary research collection, preventing a statistically number of interviews from being completed and reducing the breadth of secondary research collected. Additionally, the voluntary nature of interviews does create challenges with self-selection and preventing an entirely randomized sampling process. 


\subsection{FINDINGS}

\subsection{Professional InTerviews}

Professional participants from both City agencies and departments and BIAs were included in the study. A unique set of questions was asked of both BIA and City respondents, containing several overlapping questions where appropriate. Questions were designed to elicit comments on current practices and for professional opinions to be conveyed. A total of six professional interviews were conducted from both City and BIA personnel in Toronto and Vancouver. Questions unique to each group of participants have been indicated. Perspectives for each question asked are discussed below.

When respondents were asked "Do you think involvement of BIAs is appropriate for increasing climate change resilience in your city, and why?", the general response was 'yes' there should be BIA involvement in increasing climate change resilience in their city, but questions surrounded what capacity and role BIAs could play.

From the BIA perspective, resilience initiatives were not typically seen as the focus of or central to projects undertaken by their organizations, but if there was an opportunity to identify resilience initiatives as a positive spillover as part of a project, then that aspect could be marketed and received well. One interviewee identified that general sustainability efforts could derive great benefit, but trying to sell their membership on specific resilience efforts was not an easy task due to mandate restrictions (personal communication, 2017).

The City perspective provided a stronger dichotomy of responses. One interviewee directly identified that environmental initiatives such as resilience projects have positive economic motivations and could directly affect the attractiveness of a city such as 
enabling the attraction of good employees to ensure businesses remains competitive (personal communication, 2017). Another interviewee identified a BIAs as an important collaborative mechanism, citing neighborhood focused organizations that have a vested interest are increasingly having a more important role in promotion of resilient communities. The challenges as they identified was to find the appropriate balance where collaboration and communication work best (personal communication, 2017).

Others were reticent to take a firm stance on the proposition, pointing out that BIA mandates were generally concerned with business promotion. BIAs do not currently have a mandate to address climate change and resilience in their city and even if they wanted to, BIA budgets varied so significantly that generally resilience to extreme weather events is a small concern to standing beside beautification and event promotion (personal communication, 2017).

When respondents were asked "Have BIAs been involved in resilience focused initiatives in your City?", responses varied with perceived notions of resilience initiatives. Some respondents were quick to point out that resilience was not the focus of their BIAs initiatives, with one BIA interviewee noting that during City capital improvement work an opportunity was identified and taken to increase the number of trees and ultimately improve the degree of permeability on a street (personal communication, 2017). Another indicated that they had undertaken a project to increase the number of trees along the longest street in their BIA, one which was relatively void of trees previously. The initial capital cost was paid for the BIA but maintenance was largely taken care of by the businesses they were planted in front of (personal communication, 2017). Another BIA had perceived their resilience capabilities in a different fashion, citing their development 
of emergency preparedness plans in the event of a natural disaster, providing 72-hour post-disaster kits, post-disaster plans, and work-site secondary locations to increase continuity of work, decidedly taking an awareness and education approach ultimately (personal communication, 2017).

When respondents were asked "Are there current funding tools available to BIAs relating to infrastructure or capital programs/projects? (i.e. government programs, cost-share program, etc.), the contrasts between Toronto and Vancouver were prominent as different tools were available to each city.

In the Toronto context, it was understood that BIAs can either cost share on projects or borrow money from the City. When cost sharing, the BIA and City could split the cost of capital projects approved by each BIAs respective board and the City's BIA office to a maximum of $\$ 600,000$ per year with $50 / 50$ split. When borrowing money, BIAs can receive a loan following City approval for major capital projects such as broad streetscape improvements, payable back in installments over an agreed to cost-recovery period (City of Toronto, 2005).

In the Vancouver context, one BIA interviewee was unaware of funding tools available to BIAs as that was strictly not part of their mandate (personal communication, 2017), whereas another interviewee identified that their BIA applies for grants and funding generally from private sectors and occasionally as specific projects apply to from the City. They identified quick start capital project grant funding was available, as well as grants for transportation planning work, but generally grants for infrastructure work did not exist 
as they employed very little decision making authority on sidewalk replacement (personal communication, 2017).

From a City perspective, specific opportunities exist through local improvement charges, where the City, residential and commercial properties could cost-share on specific improvements such as sidewalk implementation, speed humps, traffic bulges or street lighting (personal communication, 2017).

When respondents were asked "Does your city currently have any policies or standards relating to resilience? (i.e. urban design guidelines, resiliency strategies, stormwater management guidelines)", it was identified that both Toronto and Vancouver have a vigorous suite of urban design guidelines, resilience strategies and stormwater management guidelines, some of which have been summarized previously in this paper. Where a deficiency was identified was surrounding specific civic improvement standards.

The City of Toronto has a comprehensive list of design details such as paving, street trees, medians, lighting, and street furniture that comprise their Streetscape Manual, but is void of explicit resilient options for use. Included in the City of Toronto's best practices manual for street tree planting are general, yet non-resilient explicit principles for planting that encourage larger soil volumes and minimizing conflict with tree roots and utilities (DTAH, 2013). In Vancouver, one interviewee noted that urban design standards are neighbourhood specific and not all areas that BIAs encompass have existing design standards (personal communication, 2017). It was generally agreed upon that the City should have design standards for resilience that can be applied to aspects of work that 
the BIAs are undertaking, and the standards need to be aesthetically pleasing enough so that the BIAs will be interested in using them.

When respondents were asked, "What do you think are some of the barriers to improving a BIAs role in resilience initiatives?", it was generally agreed upon by both BIA and City respondents that capacity, resources, and mandate were the largest barriers to BIAs improving their role in resilience initiatives. One interviewee from a BIA indicated that they simply did not have the capacity or staffing to focus on resilience issues (personal communication, 2017). Interestingly, a City interviewee indicated the definition of resilience needs to be consistent, that BIAs and the City need to have an alignment of definition through which to frame the issue for their respective audiences (personal communication, 2017).

When BIAs were asked, "How do you see BIAs evolving in the future to support or move forward with resilience initiatives?", there was general optimism with their role moving forward and an agreement that education would be central to their role. It was also clear that the BIAs with larger operating budgets also saw opportunities to make incremental infrastructure and physical resilience improvements through public realm initiatives. One interviewee identified that resiliency against climate change will be high on everyone's mind as we move into the future and specifically as regulations come in from the City that apply to businesses, BIAs were in an excellent position to align their programming and inform their membership (personal communication, 2017). Finally, it was identified by all interviewees that relationship building between BIAs and the City was paramount to moving forward. 
When City respondents were asked, "How do you see cities evolving in the future to support BIA involvement with resilience initiatives?", there was overarching recognition of the importance of BIAs moving forward and their ability to implement incremental quick wins, but barriers would need to be addressed such as funding, capacity, and increased collaboration. In Vancouver, it was stated that City did not currently have a structure in place to support businesses that may come to them with an idea for an initiative; there was a lack of funding structure in place to support this (personal communication, 2017). Another interviewee identified that it was imperative to create a strong business case that would ensure long-term benefit projects were able to appropriately bundle shortterm benefits as a selling feature to BIA membership (personal communication, 2017). Finally, one interviewee supported the notion of an incremental approach, noting that resilience can be a neighbourhood-specific initiative and BIAs are well positioned to act as champions for their districts (personal communication, 2017).

\subsection{Toronto BiA Resilience Policies and Programs Findings}

\subsubsection{TORONTO FinAncial District Bia}

The Toronto Financial District Business Improvement Area (TFDBIA) has a mandate to promote economic development within the area and identify "collaborative opportunities that ensure the Financial District and PATH are well-maintained, integrated, connected and accessible" (Toronto Financial District BIA, 2014, p. 2). To carry out the mandate a public realm strategy, Raising the Standard was developed in 2012. The strategy is updated annually and identifies a positive economic return on public realm improvements and seeks to maximize these returns on through long-range collaborative planning initiatives while leveraging City of Toronto capital works to improve central tenets of the 
strategy - improvement of area operations and aesthetics. The 2016 annual update to the public realm strategy saw the inclusion of a resilience framework, whereby resilience opportunities with existing projects should be incorporated, such as burying overhead power lines, increasing permeability throughout the area, targeted tree planting, and identifying infrastructure hardening opportunities through existing capital work (Toronto Financial District BIA, 2016, p. 4)

\subsubsection{Downtown Yonge BIA}

Since 2011, included in the Downtown Yonge Business Improvement Area's (DYBIA) mandate has been to improve the public realm through their Public Realm Strategy, that identifies investments in the public realm represent a positive impact on the economy. The strategy identifies several distinct precincts within their area to appropriately target capital work investments. Included in the benefits of streetscape improvements are enhancement of economic vitality and strengthening the community and overcoming challenges (Downtown Yonge BIA, 2011). Capital project improvements undertaken by the DYBIA have included enhancing greenery, installing tree grates to protect trees and sidewalk improvements.

\subsection{Vancouver Bia Resilience Policies and Programs Findings}

\subsubsection{Downtown VAncouver BIA}

The Downtown Vancouver Business Improvement Association (DVBIA) has a 5-year strategic plan that outlines an established set of key values and guiding principles including: "Sustainability: Facilitate a robust and resilient community focused on economic, social and environmental success" (Downtown Vancouver BIA, 2012, p. 1). Further, the DVBIA has published a vision for Downtown Vancouver in 2040, Downtown 
Vancouver Re-Imagined, a high-level vision of what the DVBIA along with other stakeholders can implement to improve the experience for people in downtown. Several identified desires of what downtown Vancouver is to look like in 2040 are included, such as the prescription that downtown Vancouver is powered by $100 \%$ renewable energy through district energy systems, downtown Vancouver is rain-proofed, including the harvesting of water for irrigation, and increased street trees. While the vision includes several strong initiatives for increasing resilience, among the 11,000 who provided feedback that went into the report, only $3 \%$ of respondents identified Green initiatives/infrastructure as one thing that would make downtown Vancouver a "world class city" (Downtown Vancouver BIA, 2015, p. 55).

\subsubsection{StrathConA BIA}

The Strathcona Business Improvement Area (SBIA) issued a policy document in 2015 to outline their mission, mandate and vision for their area. Specific to their mandate includes a mission to "build a co-operative, safe, and vibrant Strathcona through innovative programming and community collaboration" (Strathcona BIA, 2015, p. 2) and a vision that includes being a model for sustainability. Embedded within the document are a series of positions the BIA takes including that new development should enhance local business resiliency. The SBIA is also well-known for the Green Zone initiative, a commercial recycling and composting program that received $\$ 100,000$ in funding from the City of Vancouver and Metro Vancouver to assist in constructing a resource park to serve as a space for materials exchange, recycling hub, and urban garden plots (City of Vancouver, n.d.). 


\subsection{SUMMARY OF FINDINGS}

Several common themes emerged through this research study that help to understand the current and future role of Business Improvement Areas in increasing resilience in their cities.

\subsubsection{MANDATE}

It is generally acknowledged that the primary focus of BIA activities is not on resilience and nor should it be. BIAs have many diverse mandates, ranging from business promotion through events, marketing, attracting shoppers, and small-scale streetscape improvements to district-wide economic competitiveness advocacy and multi-milliondollar capital project improvements. From the primary interviews, it was observed that level of resilience involvement varied across BIAs and currently was not widely accepted as a priority for investment, and this was largely confirmed through the scan of policies and programs currently being advanced by BIAs.

\subsubsection{BUDGET}

Budgets vary widely for BIAs, ranging from shoe-string budgets in the thousands, to much larger budgets in the millions. With the average annual budget for a Vancouver BIA being roughly $\$ 250,000$ (personal communication, 2017), and the average for Toronto being roughly $\$ 350,000$ (City of Toronto, 2016), typical BIA budgets are quite prohibitive for incorporating resilience initiatives when a great number of in-scope, cost-effective quick wins are attainable. Certain funding mechanisms do exist however, such as capital cost sharing and capital project loans in Toronto and annual budget allocation following BIA renewal in Vancouver, do offer some financial flexibility. Additionally, some grants and 
external funds are available to BIAs, but the inconsistency and scope of these grants do not make them reliable forms of funding.

\subsubsection{CAPACITY}

It was clearly observed that not all BIAs have the expertise, experience, or staff required to incorporate resilience initiatives in their programming and projects. BIAs typically have smaller teams, often less than 10 employees and more often than not they do not have a planner or similarly qualified staff member on their payrolls. It was observed that resilience is viewed as an emerging area and guidance and support are imperative to BIA involvement with resilience initiatives.

\subsubsection{Collaboration ANd Partnership}

Through the primary interviews the need for collaboration and partnership was clearly identified. The intimate area knowledge possessed by BIAs was understood and as cities are moving forward with their own resilience initiatives, appropriate collaboration and partnership was required. Through the scan of resilience supportive actions, recommendations and directions of City policy documents to collaborate and partner with external stakeholders is gaining in prominence. 


\subsection{Recommendations ANd Conclusion}

\subsection{ReCOMMENDATIONS}

BIAs currently operate in unique place, occupying space between the public and private sectors. These recommendations are focused on areas to help improve BIA positions as viable and capable stakeholders and partners for cities to collaborate with in offsetting the high costs of improving resilience.

Recommendations are based on the emergent themes identified from the components of this research and the review of resilience supportive actions. As budgets have been identified as a significant barrier to improving a BIAs role in increasing climate change resilience in cities, these recommendations are suitable for BIAs that have achieved what Millar (2015) calls "phase three" in the evolution of BIAs. In phase three, BIAs have developed strong reputations for their improvements in the public realm, hold significant intimate local knowledge that has the capability to benefit the broader public, and seek to expand their capacity as leaders with strategic long-range planning.

There is an assumption inherent to achieving phase three where a BIA would likely require substantial financial stability and flexibility to insert themselves into the conversation of resilience building.

\subsubsection{MANDATE:}

1. BIAs are encouraged to illustrate the business case for resilience to their membership. If appropriate membership education is undertaken, a stronger impact for resilience initiatives will be realized.

2. BIAs are encouraged to incorporate resilience language into their strategic plans. This will provide justification for the incorporation of resilience initiatives. 
3. City BIA offices are encouraged to work with BIAs who wish to incorporate resilience initiatives into their mandates.

\subsubsection{CAPACITY:}

4. BIAs are encouraged to identify the individual shocks and stressors relating to their area and develop appropriate action plans. This will help BIAs to develop resilience expertise to direct positive incremental resiliency within their areas.

5. City agencies, departments, and corporations are encouraged to develop appropriate resilience urban design guidelines and standards. If BIAs are to incorporate resilient elements into their projects, City standards must be of highquality to ensure they are used.

\subsubsection{Collaboration ANd Partnership:}

6. City staff are encouraged to help BIAs evaluate their strategic plans with a resilience lens and identify goals which BIAs can help advance through existing or new programs (i.e., tree canopy targets as part of streetscape projects).

7. City agencies, departments, and corporations are encouraged to increase involvement of BIAs in resilience related working groups.

8. City agencies, departments, and corporations and BIAs are encouraged to develop and align definitions of resilience.

9. City agencies, departments, and corporations are encouraged to develop or expand resilience education campaigns, including improving BIA awareness of relevant tools at their disposal. 
10. Cities agencies, departments, and corporations are encouraged to update relevant guidelines to emphasize resilience benefits were appropriate (i.e., tree planting best practices manual).

\subsection{CONCLUSION}

This research highlights the crucial need to support partnerships that continue and advance investments in resilience supportive actions that mitigate the effects of extreme weather and climate change. Scans of policies and programs of both City entities and BIAs, along with key professional interviews, have identified climate change and extreme weather resilience as an emerging issue that requires both innovative funding initiatives and collaborative partnerships to successfully advance initiatives amidst numerous competing demands for City resources. As BIAs grow in sophistication and begin to position themselves as stewards and champions of their respective areas, a unique opportunity exists for Cities to partner with BIAs to collectively improve a city's resilience on an incremental, district approach. 


\section{ApPendix: Professional InTERView Questions Interview Questions for BIA staff:}

Do you think involvement of Business Improvement Areas (BIAs) is appropriate for increasing climate change resilience in your city, and why?

If answer to "Do you think involvement of Business Improvement Areas (BIAs) is appropriate for increasing climate change resilience in your city, and why?" was NO:

- What do you think are some of the barriers to improving a BIAs role in resilience initiatives?

- Have BIAs been involved in resilience focused initiatives in your City?

$\circ$ If yes, please give some examples.

- Are there current funding tools available to BIAs relating to infrastructure or capital programs/projects? (i.e. government programs, cost-share program, etc.)

○ If yes, are there restrictions on how that funding is allocated or spent?

- Does your city currently have any policies or standards relating to resilience? (i.e. urban design guidelines, resiliency strategies, stormwater management guidelines)

- If yes, please give some examples.

If answer to "Do you think involvement of Business Improvement Areas (BIAs) is appropriate for increasing climate change resilience in your city, and why? " was YES:

- Has your BIA been involved with any resilience focused projects?

- If yes, Why and how did your BIA get started with resilience initiatives?

- Are there current funding tools available to BIAs relating to infrastructure or capital programs/projects? (i.e. government programs, cost-share program, etc.)

- If yes, are there restrictions on how that funding is allocated or spent?

- How do you see BIAs evolving in the future to support or move forward with resilience initiatives?

- Does your city currently have any policies or standards relating to resilience? (i.e. urban design guidelines, resiliency strategies, stormwater management guidelines)

- If yes, please give some examples. 


\section{Interview Questions for City staff:}

Do you think involvement of Business Improvement Areas (BIAs) is appropriate for increasing climate change resilience in your city, and why?

If answer to "Do you think involvement of Business Improvement Areas (BIAs) is appropriate for increasing climate change resilience in your city, and why? " was NO:

- What do you think are some of the barriers to improving a BIAs role in resilience initiatives?

- Have BIAs been involved in resilience focused initiatives in your City?

$\circ$ If yes, please give some examples.

- Are there current funding tools available to BIAs relating to infrastructure or capital programs/projects? (i.e. government programs, cost-share program, etc.)

- If yes, are there restrictions on how that funding is allocated or spent?

- Does your city currently have any policies or standards relating to resilience? (i.e. urban design guidelines, resiliency strategies, stormwater management guidelines)

- If yes, please give some examples.

If answer to "Do you think involvement of Business Improvement Areas (BIAs) is appropriate for increasing climate change resilience in your city, and why?" was YES:

- Is there current collaboration between City government and BIAs in your city, with respect to infrastructure or capital projects/programs?

- If yes, what form does that collaboration take?

- Are there current funding tools available to BIAs relating to infrastructure or capital programs/projects? (i.e. government programs, cost-share program, etc.)

○ If yes, are there restrictions on how that funding is allocated or spent?

- Does your city currently have any policies or standards relating to resilience? (i.e. urban design guidelines, resiliency strategies, stormwater management guidelines)

- If yes, please give some examples. 
- What do you think are some of the barriers to improving a BIAs role in resilience initiatives?

- How do you see cities evolving in the future to support BIA involvement with resilience initiatives? 


\section{REFERENCES}

100 Resilient Cities. (2017). About us. Retrieved from http://www.100resilientcities.org/about-us\#/- /

100 Resilient Cities. (2013). Building Resilience in Rapidly Growing Cities. Retrieved from http://www.100resilientcities.org/blog/entry/building-resilience-in-rapidlygrowing-cities\#/- I

100 Resilient Cities. (2015). What a Chief Resilience Officer Does. Retrieved from http://www.100resilientcities.org/blog/entry/what-is-a-chief-resilience-officer1\#/- /

Blackman, M. (2005). Achieving Economic and Social Sustainability in the Inner City: The Role of Business Improvement Districts. University of British Colombia, Vancouver.

City of Calgary. (2016). Business Revitalization Zones. Retrieved from http://www.calgary.ca/CSPS/ABS/Pages/Partnership-programs/BRZs.aspx

City of Edmonton. (2010). Façade Improvement Program: Information Package. Retrieved from https://www.edmonton.ca/business economy/documents/PDF/Facade and Storefr ont Improvement Program Information Package.pdf

City of New York. (2013). Hurricane Sandy After Action. Retrieved from http://www.nyc.gov/html/recovery/downloads/pdf/sandy aar 5.2.13.pdf

City of New York. (2013). PlaNYC. A Stronger, More Resilient New York. http://s-media.nyc.gov/agencies/sirr/SIRR singles Lo res.pdf

City of Toronto. (2005). A Proposed Financing Model for the Bloor Street Transformation Project Ward 27 - Toronto Centre-Rosedale. Retrieved from http://www.toronto.ca/legdocs/2005/agendas/committees/edp/edp050704/it024.pdf

City of Toronto. (2007). Climate Change Action Plan - Change is in the Air. Retrieved from

http://www1.toronto.ca/City\%200f\%20Toronto/Environment\%20and\%20Energy/Pro grams\%20for\%20Residents/Files/pdf/C/clean_air_action_plan.pdf

City of Toronto. (2009). Wet Weather Flow Master Plan - The Plan in Action. Retrieved from

http://www1.toronto.ca/city of toronto/toronto water/files/pdf/wwfmp 5yr implemen tation report.pdf

City of Toronto. (2012). Toronto's Future Climate: Study Outcomes. Retrieved from http://www.toronto.ca/legdocs/mmis/2013/pe/bgrd/backgroundfile-55155.pdf 
City of Toronto. (2013). Resilient City: Preparing for Extreme Weather Events. Retrieved from http://www.toronto.ca/legdocs/mmis/2013/pe/bgrd/backgroundfile-64016.pdf

City of Toronto. (2014). Best Practices in Climate Resilience in 6 North American Cities. Retrieved from https://www1.toronto.ca/City\%200f\%20Toronto/Environment\%20and\%20Energy/Pr ograms \%20for\%20Businesses/lmages/16-062014\%20Best $\% 20$ Practices\%20in\%20Climate\%20Resilience.pdf

City of Toronto. (2014). Resilient City - Preparing for a Changing Climate. Retrieved from http://www.toronto.ca/legdocs/mmis/2014/pe/bgrd/backgroundfile-70623.pdf

City of Toronto. (2015). Business Improvement Areas (BIAs) - 2016 Operating Budgets - Report No. 2. Retrieved from http://www.toronto.ca/legdocs/mmis/2016/ed/bgrd/backgroundfile-87135.pdf

City of Toronto. (2016). Business Improvement Areas (BIAs) - 2017 Operating Budgets - Report No. 1. Retrieved from http://www.toronto.ca/legdocs/mmis/2016/ed/bgrd/backgroundfile-98284.pdf

City of Toronto. (2016). Toronto City Council and Committees - Meetings, Agendas and Minutes. Parks and Environment Subcommittee on Climate Change Mitigation and Adaptation (2014-2018). Retrieved from http://app.toronto.ca/tmmis/decisionBodyProfile.do?function=doPrepare\&decisionBo dyld=1282\#Meeting-2016.PY2

City of Toronto. (2017). About the Plan. Retrieved from

http://www1.toronto.ca/wps/portal/contentonly?vgnextoid=f36807ceb6f8e310VgnVC M10000071d60f89RCRD\&vgnextchannel=972bab501d8ce310VgnVCM10000071d 60f89RCRD

City of Toronto. (2017). Green Roof Bylaw. Retrieved from http://www1.toronto.ca/wps/portal/contentonly?vgnextoid=83520621f3161410VgnV CM10000071d60f89RCRD\&vgnextchannel=3a7a036318061410VgnVCM10000071 d60f89RCRD

City of Toronto. (2017). ResilientTO. Climate Change Risk Management Policy.

Retrieved from

http://www1.toronto.ca/wps/portal/contentonly?vgnextoid=f4870093ae9b4510 VgnV CM10000071d60f89RCRD

City of Toronto. (2017). Toronto Green Standard, Making a Sustainable City Happen for New Mid to High-Rise Residential and All Non-residential Development. Retrieved from

http://www1.toronto.ca/City\%20Of\%20Toronto/City\%20Planning/Developing\%20Tor onto/Files/pdf/TGS/2017TGS MidHiRise Standard(1).pdf 
City of Vancouver. (n.d.). Strathcona Green Zone Commercial Recycling and Composting Program. Retrieved from http://www2.gov.bc.ca/assets/gov/environment/wastemanagement/recycling/organics/casestudies/cs 11 sbia.pdf

City of Vancouver. (2012). Climate Change Adaptation Strategy. Retrieved from http://vancouver.ca/files/cov/Vancouver-Climate-Change-Adaptation-Strategy-201211-07.pdf

City of Vancouver. (2016). Citywide Integrated Rainwater Management Plan: Volume 1 - Vision, Principles \& Actions. Retrieved from http://vancouver.ca/files/cov/integrated-stormwater-management-vision-principlesand-actions-volume-1.pdf

City of Vancouver. (2015). Greenest City 2020 Action Plan, Part Two: 2015 - 2020. Retrieved from http://vancouver.ca/files/cov/greenest-city-2020-action-plan-20152020.pdf

City of Vancouver. (2017). Developing Vancouver's Urban Forest Strategy. Retrieved from http://vancouver.ca/home-property-development/urban-forest-strategy.aspx

City of Vancouver. (2017). How Vancouver prepares for emergencies. Retrieved from http://vancouver.ca/home-property-development/how-vancouver-prepares-foremergencies.aspx

City of Vancouver. (2017). Prepare your business for an earthquake or other disaster. Retrieved from http://vancouver.ca/home-property-development/businessemergency-safety.aspx

Downtown Vancouver BIA. (2012). Downtown Vancouver Business Improvement Association Strategic Plan: 2012 - 2017. Retrieved from http://www.downtownvancouver.net/img/brochures/DVBIA_2012_2017_Strategic PI an January 2012 FINAL.pdf

Downtown Vancouver BIA. (2015). Downtown Vancouver Re-Imagined, A Vision for Downtown Vancouver in 2040. Retrieved from http://reimaginedowntown.com/wpcontent/uploads/2015/11/RDTVan Final Report.pdf

Downtown Yonge BIA. (2011). Public Realm Strategy. Retrieved from http://www.toronto.ca/legdocs/mmis/2015/cc/comm/communicationfile-53939.pdf 
DTAH. (2013). Tree Planting Solutions in Hard Boulevard Surfaces, Best Practices Manual. Retrieved from

http://www1.toronto.ca/city of toronto/parks forestry recreation/urban forestry/fil es/pdf/TreePlantingSolutions BestPracticesManual.pdf

FEMA. (2013). Mitigation Assessment Team Report: Hurricane Sandy in New Jersey and New York: Building Performance Observations, Recommendations, and Technical Guidance. Retrieved from https://www.fema.gov/media-librarydata/1386850803857-

025eb299df32c6782fdcbb6f69b35b13/Combined Sandy MAT Report 508post.pdf

Gomez, R., Isakov, A., Semansky,M. (2015). Small Business and the City: The Transformative Potential of Small Scale Entrepreneurship. Rotman-UTP Publishing, $1-312$

Grosvenor. (2014). Resilient Cities. Retrieved from http://www.grosvenor.com/getattachment/194bb2f9-d778-4701-a0ed5cb451044ab1/ResilientCitiesResearchReport.pdf

International Downtown Association. (2017). What is the size of the industry? Retrieved from https://www.idadowntown.org/eweb/dynamicpage.aspx?webcode=ABOUTINDUSTRY

Millar, S. (2015). BIA 2.0 Advancing the Role of Business Improvement Areas in Community Planning. Ryerson University, Toronto.

Ministry of Municipal Affairs and Housing. (2010). Business Improvement Area Handbook 2010. BIA Handbook 2010. Retrieved from https://icreate5.esolutionsgroup.ca/230886 Gravenhurst/en/yourtownhall/resources/ BIA-Handbook-2010.pdf

MNP. (2015). Review and Analysis of the Government of Alberta's Response to and Recovery from 2013 Floods. Retrieved from

http://www.aema.alberta.ca/documents/2013-flood-response-report.pdf

Munich. (2016). 2015 US natural catastrophe losses curbed by EI Niño; brutal North American winter caused biggest insured losses. Retrieved from https://www.munichre.com/us/property-casualty/press-news/pressreleases/2016/160104-natcatstats2015/index.html

Munich. (2017). Natural Catastrophe Losses at their Highest for Four Years. Retrieved from https://www.munichre.com/en/media-relations/publications/pressreleases/2017/2017-01-04-press-release/index.html

National Round Table on the Environment and the Economy. (2012). Facing the Elements: Building Business Resilience in a Changing Climate. 
Strathcona BIA. (2015). Strathcona BIA 2015 Policy Document. Retrieved from http://strathconabia.com/wp-content/uploads/2016/09/SBIA-Policy-PositionDocument-1.pdf

Toronto Financial District BIA. (2014). Raising the Standard, A Public Realm Strategy for Toronto's Financial District. Retrieved from https://www.dropbox.com/s/xoth1o3j0tmoh1f/FDBIA\%20Financial\%20District\%20Pu blic\%20Realm\%20Strategy.pdf

Toronto Financial District BIA. (2016). Raising the Standard, 2016 Update to the Public Realm Strategy for Toronto's Financial District. Retrieved from http://torontofinancialdistrict.com/wp-content/uploads/2016/11/Raising-theStandard-2016-Update-to-Public-Realm-Strategy-for-Torontos-Financial-District.pdf

Vorhies, F., \& Wilkinson, E. (2016). Co-benefits of Disaster Risk Management: The Third Dividend of Resilience. In S. Surminski \& T. Tanner (Eds.), Realising the "Triple Dividend of Resilience": A New Business Case for Disaster Risk Management (pp. 55-72). Cham: Springer International Publishing. https://doi.org/10.1007/978-3-319-40694-7_3

World Bank. (2013). Building Resilience - Integrating Climate and Disaster Risk into Development. Retrieved from http://documents.worldbank.org/curated/en/762871468148506173/pdf/826480WP0v 10Bu0130Box379862000UO090.pdf 


\title{
Glossary OF TeRmS
}

\author{
100RC 100 Resilient Cities \\ BIA Business Improvement Area \\ CRO Chief Resilience Officer \\ DVBIA Downtown Vancouver BIA \\ DYBIA Downtown Yonge BIA \\ Levy Business Improvement Area Levy \\ SBIA Strathcona BIA
}

TFDBIA Toronto Financial District BIA 